Original Research Article

\title{
Research on Debon Logistics Transportation Management
}

\author{
Jinyan Shi,Zhigang Hu,Zhuxue Jing \\ School of Logistics Management and Engineering, Yantai University of Technology, Shandong, China
}

\begin{abstract}
With the continuous development of social economy, the transportation process of trade has promoted the improvement of logistics and transportation. Modern logistics enterprises should not only have a perfect service system, but also have a good logistics and transportation so as to ensure the logistics In order to meet the needs of today's market, this paper takes the transportation of Debon logistics as an example. Firstly, it introduces the current situation of Debon logistics and transportation management, and then analyzes the problems in Debon logistics and transportation. Finally, it points out the improvement measures, The German industry to further enhance the competitiveness of enterprises have a certain guiding significance.
\end{abstract}

KEYWORDS: Debon logistics; transportation management; improvement measures

\section{Introduction}

A logistics business to achieve the high efficiency of its business, it is necessary to establish a sound logistics and transport systems, efficient logistics and transportation system can save the cost of enterprises and improve the competitiveness of enterprises in the market Therefore, now, for logistics and transport Management research has been a lot of people's attention, Debon logistics as a modern logistics enterprises in the transport management and transportation system construction has made great achievements in grams, at present, many companies are imitating this success in Debon logistics In order to improve the operation mode of enterprises to improve their own, however, there are still many problems in Debon logistics and transportation. Therefore, the research process of Debon logistics and transportation management is conducive to further enhance the development of Debon logistics enterprises. State enterprises to further expand the market to do the appropriate basis.

\subsection{Background and meaning of the topic}

Debang Logistics Co., Ltd. is a national 5A-class integrated service-oriented logistics enterprises, the main domestic highway LTL transport and air transport agency services. The company was founded in September 1996 , as of May 2013, Debon Logistics has 30 provinces, municipalities and autonomous regions to open more than 5,000 outlets, more than 67,000 employees, own transport vehicles more than 5,000 Taiwan, Taiwan The total area of more than 800,000 square meters, the daily throughput of nearly 30,000 tons, the service network throughout the country more than 550 cities and regions, covering $90 \%$ of the national economic center and population. This paper mainly deals with the problems existing in German routes and network, vehicle dispatching, transportation information system and operator.

\subsection{Research status at home and abroad}

In the 'Debon logistics and transport system development status analysis' Mr. Li Yifei on the development of Debon logistics system proposed logistics enterprises in order to achieve the high efficiency of its business, it is necessary to establish a sound logistics and transport systems, efficient logistics and transportation system Can save the cost of enterprises and improve the competitiveness of enterprises in the market, so now, for the logistics system research, has been a lot of people's attention, Debon logistics as a modern logistics enterprises in the transport system construction and development Has made great achievements. At present, many companies are imitating this success in Debon logistics to improve the operation of enterprises to improve their own business model, however, in Debon

Copyright (C) 2017 -. This is an Open Access article distributed under the terms of the Creative Commons Attribution-NonCommercial 4.0 International License (http://creativecommons.org/licenses/by-nc/4.0/), permitting all non-commercial use, distribution, and reproduction in any medium, provided the original work is properly cited. 
logistics and transportation system, there are still many shortcomings, so, for Debon logistics and transport System research process, is conducive to further enhance the development of Debon logistics enterprises. Thus, the next step for Debon enterprises to expand the market to do the appropriate basis. 1 Debon logistics status and development trend Debon logistics through five years of development and reform process, has made brilliant achievements, become a modern large AAAA class logistics enterprises. At present, 32 provinces and cities in China has opened more than 2,500 logistics only profit outlets, own operating vehicles more than 5200 Taiwan, the national transit center a total area of more than 850,000 square meters. Its transportation channels include roads, railways and aviation, and formed a set of transport, packaging, warehousing as one of the third party logistics enterprises.

In the trial of corporate logistics and transport in the existence of legal issues, Dai Jingjing proposed transport management of several of the more common legal issues overdue delivery, misuse, damage to the goods destroyed some of the problems, the corresponding number of countermeasures 1. Increase Logistics regulations and propaganda efforts to effectively avoid logistics. 2. Improve the logistics and transport prices and taxes laws and regulations 3. Improve the logistics freight forwarders legal countermeasures. And put forward the enterprise logistics and transport in the development process, cannot be separated from the sound laws and regulations system. For the time being, there are still many legal problems in the process of logistics and transportation of Chinese enterprises. It needs the relevant government departments to proceed from the development characteristics of China's logistics and transportation and the national conditions of our country, and constantly improve the laws and regulations of the logistics industry the behavior of. I believe that in the near future, China's logistics and transport industry in the legal norms, will achieve a qualitative leap.

In the 'modern logistics enterprise transport resource agglomeration model and its formation mechanism research' Wei Juan proposed the modern logistics enterprise transportation resource integration pattern, the modern logistics transportation resource integration mechanism, the logistics enterprise and the transportation enterprise longterm cooperation obtains the production chain gross profit, To be greater than the two non-cooperation when the onetime transaction to obtain profits and cooperation than non-cooperation to obtain more benefits, so small and mediumsized transport enterprises will join the logistics enterprises as the core of the network organization, the formation of Zhongwei City structure, and Logistics companies signed long-term cooperation contract.

\section{Overview of the theory of transport management}

The simplest understanding of logistics is the transport of goods, so the transport in the logistics operation of the status is very important, transport management in the entire logistics management occupies a considerable proportion. Transportation Management System (TMS) is an important part of the logistics management information platform, in the logistics operation of all aspects of transport time and cost a considerable proportion. The effective management of transportation is an important part of modern logistics management. The modern transportation management is the management of the transportation network. In this network, the transportation tasks, resource control, state tracking and information feedback are transmitted in different areas. The transportation management system is an efficient, Reliable, safe and distributed modern logistics and transportation management information system, the purpose is to transport the process of people (drivers), cars, goods, customers and cost accounting for effective coordination and management.

\subsection{The role of transport}

Transportation is one of the main functions of logistics, it changes the state of the goods and the state of space, will be separated from the space between the suppliers and demanders, and the supplier can be within a reasonable time to provide items to the demand. Transportation provides the function of item displacement and short-term inventory.

The transportation management of the logistics enterprise is the reasonable organization, unified use, real-time control and supervision of the human, material, financial and transportation equipment in the various departments, all links and transportation plans, transportation, transportation and transit of the whole transportation process In order to use the same labor consumption, to create more transport value, to provide quality services to customers colleagues, to maximize their own business profits.

\subsection{Overview of logistics and transportation management}

Logistics and transport management and other enterprises as the management of transport, mainly including the following three parts: 


\section{Transportation decision-making.}

Decision-making ability is the core competitiveness of third-party logistics companies. Transport decisionmaking when the entire transport management of the early work, the transport management riding a pivotal role. This is the business in the transport management operations before the transport mode of transport, transport routes, transport time selection, transportation cost budget, transport personnel and transportation insurance and other options, come up with the best program.

\section{Transport process management}

The management of the transport process is the core of the entire transport management, including the management of shipments, transfers, transfers and transport safety, and the flow of personnel and capital flows into the movement of goods. Shipping management mainly coordination of cargo and car convergence, including the implementation of supply, check the packaging mark, arrange short-distance handling, handling consignment procedures and so on. But also in strengthening the packaging, cleaning and replacement damage. to strengthen the work to improve the quality of transport. Transportation safety management, including the establishment of the transport safety system to prevent the occurrence of transport accidents; after the accident in a timely manner to deal with, to avoid the backlog of wrangling, long-term suspension and so on.

\section{Transport settlement management}

This is the last link in transport management. Transport settlement management, including transportation costs calculation and accounting treatment, including claims and deal with other claims, transport equipment maintenance and storage and so on.

These three aspects of the specific content is reflected in the practical operation is: the choice of mode of transport and service; transport route selection, vehicle scheduling and organization; freight to determine and consider.

\section{Status of Debon Logistics Transportation Management}

\subsection{Operation of Debon Logistics and Transportation Management}

Debon logistics company was established in September 1996, is the SA-class logistics enterprises. So far, the logistics business expanded to more than 30 provinces, municipalities and autonomous regions, direct outlets more than 4,500, more than 30,000 employees, self-transport vehicles 8,800 Taiwan, the daily flow of goods close 60,000 tons, the total area of the national transit center more than 970,000 square meters.

Debon logistics company to 'carry trust, help success' as a corporate service concept, pay attention to personnel training, to ensure the quality of logistics services, and through the construction of information management systems and technological innovation to improve the network transport mode and standardization system, to provide Fast, professional, safe, satisfied with the service. Debon logistics is committed to building enterprises and employees win-win development model, in improving the staff logistics business capacity at the same time, promote social and economic development, contribute to the community. Debon Logistics Company is trying to become the preferred logistics operators, to achieve 'for China's speed' mission. However, Debon Logistics Company is also the advantages and disadvantages of coexistence of enterprises. At present, Debon logistics company's advantage lies in the implementation of information technology, scientific management; staff work more practical; specialized recruitment graduates; corporate culture gradually improved; established a reserve cadre system; company development speed; additional value-added services. Debon logistics company's disadvantages include the management concept is slightly outdated; professional logistics talent less; transport costs; lack of strong combination between enterprises; development business is more single; self-transport vehicles more.

\subsection{Debon logistics transport routes}

At present, Debon logistics company in the country 30 provinces, municipalities and autonomous regions to open more than 3,000 business outlets, service network throughout the country more than 500 cities and regions, covering $90 \%$ of the national economic center and population, but relatively concentrated in the eastern coastal developed cities, The central and western parts of the mountain because of the degree of economic development is relatively backward, the volume is small, assuming that the network income is low. Therefore, the central and western regions of the sparse network is not conducive to the construction of enterprise transport, at the same time, High, resulting in a waste. 
In this case, the actual situation of Debon Logistics in Xiamen City is analyzed. Xiamen Debon logistics company is known as the location of 0 points, respectively, to the surrounding number $1,2,3,4,5,6,7,8,9$ a total of nine small customer points transport items, including a 7 tons of vehicles And two 11-ton cars, seven trucks maximum capacity of 300 auto parts, 11 tons of trucks maximum load of 500, set the distance from the point $\mathrm{C}$, save the distance $\mathrm{C}$, the demand for each $\mathrm{R}$, each Car mileage is $\mathrm{L}, \mathrm{L} \leq 600 \mathrm{~km}$, customer points $1,2,3, \ldots 9$ as shown in Table 1-1.

表 1-1 各点的需求量和配送距离

\begin{tabular}{|c|c|c|c|c|c|c|c|c|c|}
\hline \multicolumn{1}{|c|}{ 客户 } & 1 & 2 & 3 & 4 & 5 & 6 & 7 & 8 & 9 \\
\hline 荋求量 (个/日) & 180 & 120 & 120 & 60 & 80 & 220 & 70 & 90 & 200 \\
\hline 配送距离 (km) & 7.59 & 8.92 & 18.67 & 17.03 & 5.7 & 15.38 & 8.7 & 8.15 & 8.25 \\
\hline
\end{tabular}

(资料来源, 夏门德邦物流信息系统)

The basic situation of the number of drivers required for the mileage of each transport line is shown in Table 1-2.

表 1-2 配送信息表

\begin{tabular}{|l|l|l|l|l|}
\hline 路线 & 运距 & 运货量 & 车型 & 司机 \\
\hline $0-1-2-0$ & $21.37 \mathrm{~km}$ & 300 & 7 吨货车 & 1 \\
\hline $0-3-4-0$ & $37.34 \mathrm{~km}$ & 180 & 7 吨货车 & 1 \\
\hline $0-5-6-0$ & $31.54 \mathrm{~km}$ & 300 & 7 吨货车 & 1 \\
\hline $0-7-8-0$ & $20.27 \mathrm{~km}$ & 160 & 7 吨货车 & 1 \\
\hline $0-9-0$ & $16.50 \mathrm{~km}$ & 200 & 7 吨货车 & 1 \\
\hline
\end{tabular}

(宾料来源: 夏门徳邦物流信息系统)

On the table we can see that the company needs 7 tons of cargo vehicles daily 5 car transport, the driver 5 times the total transport mileage of $127.02 \mathrm{~km}$.

\subsection{Debon logistics and transportation information system}

Debon logistics in the transport information system management, in most cases still rely on the form of artificial, which led to its system information processing capacity is limited, cannot reasonably manage the system, including warehousing information, transportation information, logistics operations management Information communication between the three will have a problem, such as items have been out of the library, the staff did not follow the process in time for the system for the record, it will lead to the identification of this piece of any information, which will bring the German logistics company Big loss. There is a situation that is the storage of goods out of the library, but this piece cannot find, this situation is the operator did not transport the vehicles and lines. in the system to do the record.

\subsection{Debon logistics transport vehicle scheduling}

Debon logistics company has 30 provinces, municipalities and autonomous regions to open more than 1,200 business outlets, Taiwan area of nearly 410,000 square meters, the daily throughput of more than 13,000 tons, the service network throughout the country more than 550 cities and regions, Covering $90 \%$ of the country's economic center and population. Debon logistics company since the beginning of the development of green transport in 2001, has now developed to 24 cities in the country with green and large cargo transit base, to provide customers with high quality freight services. If the transport vehicle in the middle of a fault lamp problem, the freight transit base will be the first time to send vehicles to replace the faulty vehicle, greatly facilitate the transport vehicle scheduling. 


\section{Problems in Transportation Management of Debon Logistics Enterprises}

\subsection{Driver quality is low, resulting in damage to the goods}

Many drivers are relatively low academic qualifications, the intensity of training is relatively low, resulting in brutal driving phenomenon, prone to accidents, the goods in the container is also vulnerable to damage.

\subsection{Transport a single way}

At present, Debon logistics and transport system to take a single type of transport transport, this transport system is mainly concentrated in the highway collar cloud model, although this form of transport is now the logistics and logistics leader, but with the China's transport industry's further development and construction process, multimodal transport, commercial distribution system will also be rapid development. The development of these transport systems, is the German state single transport system is very weak, at the same time, with China's high-speed rail technology development and construction, there will be more cheap and convenient rail zero transport form. This will give Debon's existing logistics and transportation system a huge impact.

\subsection{Debon logistics and transportation information system construction lag}

Debon logistics in the transport system management, in most cases still rely on the form of artificial, which led to its system information processing capacity is very limited, cannot reasonably manage the system, including storage information, transport information, logistics operations management information. There is no good communication between the three. Because there is no public information exchange platform, so the Debon logistics and transportation system of information exchange form of the loss of practical application value, this transport system, cannot achieve a good vehicle out of work, the information processing capacity is not high, affecting the enterprise The normal operation of the work, leading to the occurrence of this situation may also make information technology personnel less, cannot achieve its rapid development of information technology

\subsection{Debon logistics transport vehicles themselves, the higher the cost of transportation}

Debon logistics transport vehicles are mostly old-fashioned transport vehicles, the site is higher, high fuel consumption, personnel handling time is more time, need to send staff to coordinate operation, resulting in increased staff costs.

\section{Improvement Measures of Debon Logistics Transportation Management}

\section{1. to carry out activities with the University of cooperation, recruit some high-quality, strong ability of college students.}

To carry out activities with the University of cooperation, the company's philosophy and the future development of the University, and find some high-quality ability of college students to work to enhance the German industry in this piece of the overall competitiveness of the staff.

\subsection{Increase the way the logistics transport, should not only be limited to self-purchased} vehicles.

In the future, Debon enterprises in order to compete in the market still have their own strength, it must be required from the single-type joint transport system to come out, to the form of more real transport, with China's railway and aviation development, more Type transport is bound to be the development trend of logistics and transportation, therefore, Debon logistics should make full use of a variety of transport resources, if necessary, and external logistics companies can cooperate to achieve vehicle resource sharing, and then for the enterprise to expand the logistics market to make full preparations.

\subsection{Construction of transport and communications equipment, so that Debon logistics information system to receive the first time to convey information.}

To speed up the information construction of Debon transportation system, we must first add transportation and communication equipment, and then strengthen the information transmission capacity of the whole system, improve the circulation capacity of information and the accuracy of information transmission, but also to realize the comprehensive GPS System supervision, this technology can be scientific and effective planning of the transport network to improve 
the transport and utilization of vehicle scheduling, good sound transportation and communication equipment, to achieve storage letters, transport information, logistics operations management information, communication and contact between the three Process, which greatly facilitates the management and coordination of transport systems.

\subsection{And car companies to develop low floor, low center of gravity transport vehicles, improve operational efficiency.}

To solve the current Debon enterprise logistics and transportation system inefficient problem, we must first solve the vehicle problem, for the road transport logistics enterprise vehicle problem, for the road transport logistics vehicle problems affect the entire transport efficiency and cost of the key, so it must To purchase more excellent trucks, which requires the German companies to join the vehicle manufacturing companies from the new transformation or procurement, requiring the automotive industry to create a low floor, low center of gravity, low fuel consumption of transport vehicles, thereby enhancing the transport The speed of vehicles, to speed up the efficiency of the transport process, while saving transportation costs.

\section{Conclusions}

Debon logistics business development is very successful, the overall development of Debon logistics status and development trends, the success of Debon enterprises, with many factors, but in the transformation of modern largescale logistics enterprises in the process of its transport The system also has some problems, improve its transmission system is the key to the development of Debon enterprises in the first stage, the transport system in a single form of transport, transport system efficiency, transport vehicle problems, transportation information system behind the problem is Debon logistics enterprises urgent Need to solve the problem, so the analysis and research on the status quo of Debon logistics and transportation management can effectively help the future development of Debon enterprises better.

\section{References}

1. Que Lijuan. Transportation management practice. Peking University Press .2013.02

2. Wang Jun. Analysis and Design of the Third Party Logistics Transportation Management. Shandong University .2013.6

3. Xu Shujun. Modern Logistics Management Peking University Press

4. Ru Yihong. Logistics operation management. Tsinghua University Press .2013.01

5. Li Yifei. Debon logistics transport system development status analysis. Suihua College of Economics and Management .2014 .03

6. Li Jinhua. Brief introduction to express logistics enterprise cost management. Guigang vocational college .2014 .02

7. Dai Jingjing. Try to explore the legal problems in the logistics of enterprise logistics. Inner Mongolia Vocational and Technical College .2015 .2

8. Wang Xifu, Su Shuping. Internet of things and modern logistics. Electronic Industry Press .2013.1

9. Wei Juan. Modern logistics enterprises transport resource agglomeration model and its formation mechanism. Inner Mongolia University of Finance and Economics Business School 2014.2

10. Li Yihua. Multi-agent based on logistics and distribution vehicle scheduling decision-making method. Central South University 2012.12 